\title{
The repowering of vertical axis water mills preserving their cultural heritage: techno-economic analysis with water wheels and Turgo turbines
}

\author{
Emanuele Quaranta \\ European Commission Joint Research Centre Ispra Sector, Ispra, Italy \\ Toni Pujol \\ Universitat de Girona, Girona, Spain, and \\ Maria Carmela Grano \\ CNR, Potenza, Italy
}

\begin{abstract}
Purpose - The paper presents a techno-economic analysis of the electromechanical equipment of traditional vertical axis water mills (VAWMs) to help investors, mill owners and engineers to preliminary estimate related benefits and costs of a VAWM repowering.

Design/methodology/approach - Two sustainable repowering solutions were examined with the additional aim to preserve the original status and aesthetics of a VAWM: the use of a vertical axis water wheel (VAWW) and a vertical axis impulse turbine. The analysis was applied to a database of 714 VAWMs in Basilicata (Italy), with known head and flow.

Findings - Expeditious equations were proposed for both solutions to determine: (1) a suitable diameter as a function of the flow rate; (2) the costs of the electromechanical equipment; (3) achievable power. The common operating hydraulic range of a VAWM (head and flow) was also identified. Reality checks on the obtained results are shown, in particular by examining two Spanish case studies and the available literature. The power generated by the impulse turbine (Turgo type) is twice that of a VAWW, but it is one order of magnitude more expensive. Therefore, the impulse turbine should be used for higher power requirements $(>3 \mathrm{~kW})$, or when the electricity is delivered to the grid, maximizing the long-term profit.

Originality/value - Since there is not enough evidence about the achievable performance and cost of a VAWM repowering, this work provides expeditious tools for their evaluation.
\end{abstract}

Keywords Pico hydropower, Renewable energy, Rural cultural heritage, Turgo turbine, Water mill,

Water wheel

Paper type Research paper

(c) Emanuele Quaranta, Toni Pujol and Maria Carmela Grano. Published by Emerald Publishing Limited. This article is published under the Creative Commons Attribution (CC BY 4.0) licence. Anyone may reproduce, distribute, translate and create derivative works of this article (for both commercial and noncommercial purposes), subject to full attribution to the original publication and authors. The full terms of this licence may be seen at http://creativecommons.org/licences/by/4.0/legalcode

The authors thank Mirco Semprini for sending his book Morganti and Simprini (1999), Steve Ritchie of Heidra and Jakub Hojdar of CNV TVAR for the costs of Turgo turbines, Roberto Rivolta of Bonfiglioli for the gearbox and motor costs, and Marco Gatta of Gatta srl for the water wheel costs. Data of the case study (Appendix 3) were collected by Carles Nogareda Burch, who rebuilt the water mills discussed in the present article. The authors thank MariaGrazia Sbarboro, Emanuela Genre, Patrizia Geymonat, Donata Gayard, Ludovico de Maistre, Michele Nardi, Giovanna Recati, Agostino Sichi and Pietro Ingenito for giving their opinion and speaking about their past experience in this field. The authors express special thanks to Silvano Bonaiuti and AIAMS, Italian Association of Italian Ancient Mills.

Received 10 March 2021 Revised 29 April 2021 22 June 2021 Accepted 2 July 2021 mechanical equipment of water mills 


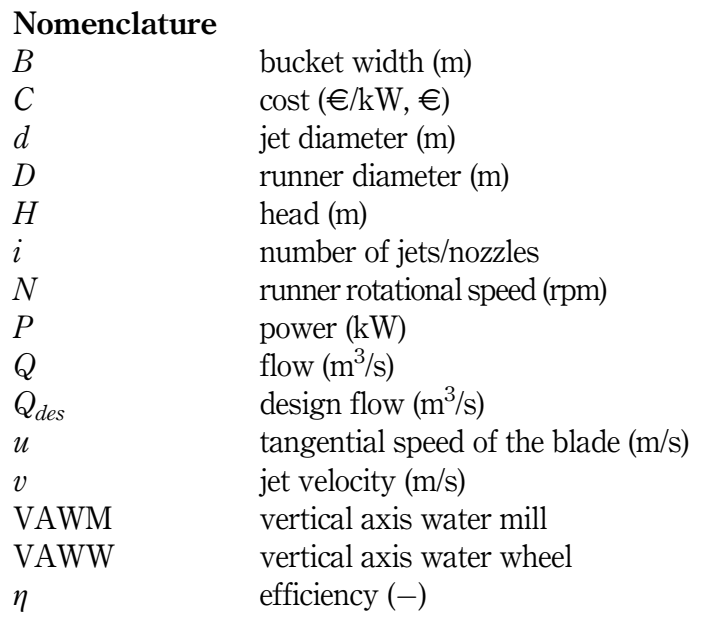

\section{Introduction}

Water mills, by harnessing the energy of water, were developed for traditional production and works, e.g. grain grinding and wood sawing, with a central role in the shaping and evolution of the cultural landscape (Brykała and Podgórski, 2020). Water mills are thus part of the industrial and cultural heritage. Their preservation and management are challenging, due to the abandonment of these structures and the lack of knowledge about their value (Çorapçıŏglu, 2016). Additional obstacles that are faced in their preservation and retrofitting are the lack of economic incentives, complexity of legislations and complex authorizations.

Until the first half of the 19th century, water mills were in widespread use around the world (Punys et al., 2019). For example, there were at least 66,000 water wheels operating in France in 1826 (Dupin, 1828), 25,000-30,000 in England in 1850 (McGuigan, 1978) and 55,000 in the United States in 1840 (Hunter, 1979). In Germany, 58,000 mills operated in 1882 (Müller, 1899) and 33,500 water wheels with power output ranging from 0.75 to $75 \mathrm{~kW}$ were licensed as late as 1925 (Kur and Wolf, 1985). In Poland, almost 10,500 water mills operated in the late 18th century (Fajer, 2018), while in Japan $56 \%$ of total power generation was provided by water wheels as late as 1886 (Minami, 1982).

Throughout most of the 20th century, the vertical axis water mill (VAWM) was usually thought to be the earliest (oldest) stage of hydraulic grinders when compared to the more efficient and powerful horizontal axis mill (Curwen, 1944, p. 134), but archaeological findings contradict this hypothesis and show that the VAVM is three centuries younger than the horizontal one (Grano, 2020) (see Appendix 1 for more technical and historic details). In Ireland, 153 sites of early medieval water mills have been discovered, which have been dated to the period 612-1124 (Rynne, 2000). There are nearly 200,000 VAWMs in Indian Himalayan region, of which about 60,000 in Uttarakhand state, where $65 \%$ are in operation annually; $25 \%$ are run seasonally, and 10\% are abandoned (Vashisht, 2012). The VAWM has been in use until the 20th century in many countries, such as Portugal (Durand, 2003), France and Scotland, Central and Southern Italy (Buonora, 2010; Genise, 2011; Centofanti et al., 2013; Grano, 2020).

The use of water wheels, both the vertical and horizontal axis type, almost disappeared in the 20th century. For example, in Hungary, the number of water mills reduced from 13,474 in 1863 to 291 in 2011 (Szabo and Sallay, 2019). This was mainly caused by the advent of large 
hydro plants and electric motors, and because the efficiency of vertical axis water wheels (VAWWs) (24-29\%) was low in comparison to the efficiency of hydraulic turbines (Pujol et al., 2010). This is the reason why most of Spanish water mill owners converted the water wheels into turbines (see, e.g. Rojas-Sola and Lopez-Garcia, 2007). Furthermore, water mills require major maintenance works which are tiring and demanding (Grano and Lazzari, 2017).

Nevertheless, the importance of VAWM cultural heritage as local drive for cultural activities, tourism and development of local and small economies (Çorapçığlu, 2016), supported by modern wheel designs with efficiency up to 50\% (Pujol et al., 2010), could be of high interest in remote localities and rural areas. Two case studies are presented in Appendix 3 to support this statement. The rehabilitation of VAWMs can represent an interesting strategy to promote the sustainable development of rural areas, to preserve the cultural heritage and to generate decentralized energy, especially in areas with a large presence of VAWMs, e.g. in Basilicata (Italy). However, the evidence about costs and performance associated to the VAWM repowering is still scarce in the literature, and a few applications for electricity generation have been presented (Rojas-Sola and Lopez-Garcia, 2007; Behari and Bhardwaj, 2014). Therefore, there is a lack of data and tools to support feasibility analyses of a VAWM repowering.

The main costs related to the repowering and retrofitting of a mill are associated to the electromechanical equipment, the civil works on the hydraulic structures and on the building, authorizations and bureaucracy related to the renewal of the water concession. In order to share more light and to add a piece of knowledge in this context, in this study a technoeconomic analysis was performed to estimate costs, dimensions and performance of two electromechanical equipment types. Since the repowering of a VAWM usually has to preserve the status and the aesthetics of the site and of the structure, the two electromechanical solutions investigated were a VAWW and an impulse turbine. The impulse turbine can be considered as the most modern and optimized VAWW type. It is more efficient, but more expensive, and the trade-off between costs and power has not been adequately investigated in the literature.

A wide range of combinations of heads (water column exploited by the wheel/turbine) and flow rates was considered, using the input conditions of 714 VAWMs in Basilicata, Italy. Among these, 700 were grinders, 3 oil expellers and 11 wheat threshers. The wide range of investigated conditions made reasonable any generalization of results outside of the context here investigated, in support of engineering decisions. The achievable electric power, the required runner dimensions (the word "runner" refers both to the wheel and to the impulse turbine) and the related costs were quantified. Simple equations were proposed as preliminary evaluation tools to determine: (1) the operating hydraulic range of a VAWM; (2) a preliminary diameter as a function of the flow rate; (3) the costs of the electromechanical equipment as a function of power and head. Two case studies and some reality checks were also presented.

\section{Method}

The method consisted firstly in the data collection (section 2.1) and then in the technoeconomic analysis of the VAWMs collected in the database, focusing on the electromechanical equipment (section 2.2).

\subsection{Vertical axis water mills in Basilicata, Italy: data collection}

The census of hydraulic structures in the Basilicata Region (South Italy) was carried out through the collection of archival unpublished documents and through bibliographic and cartographic research; several archival documents and bibliographic sources were studied/ consulted to create a large georeferenced map with more than 800 mills, using data from the hydrographic map of the Italian Kingdom and cross-referencing them with other

\author{
Electro- \\ mechanical \\ equipment of \\ water mills
}


cartographic sources (Grano and Lazzari, 2017). The predominant kind of water mill found in the Basilicata Region was of the "drop tower penstock" type (see Appendix 1). In most cases, abandoned ruins were found. Some mills have been converted into houses and retain only the original external structure and rarely any machinery. There are almost 20 water mills in a good conservation state in the region, including hydraulic structures, which have been documented by photos and schedules. Some fulling mills were converted into grinding mills during the 19th century, probably for economic advantages (Grano, 2020). Only a few grinding mills with horizontal axis were found.

In the collected database (Grano, 2017), the original head $H(\mathrm{~m})$, and the minimum $Q_{\text {min }}$, maximum $Q_{\text {max }}$ and average $Q_{\text {avg }}\left(\mathrm{m}^{3} / \mathrm{s}\right)$ flow rates were specified for each VAWM. The average head was $H=7.6 \mathrm{~m}$, ranging from $2.8 \mathrm{~m}$ to $15 \mathrm{~m}$ (the head is defined as the tower height, thus the water column exploited by the wheel), with an average flow of $110 \mathrm{l} / \mathrm{s}$, ranging from $10 \mathrm{l} / \mathrm{s}$ to $400 \mathrm{l} / \mathrm{s}$. There was one site with $45 \mathrm{~m}$ head, but it was discarded as probably an outlier. The flow rate in VAWMs is generally regulated by the mill owner through a nozzle, so that the head can be maintained constant as the flow changes. We used this database in order to consider a dataset with a large range of hydraulic characteristics that are typical of VAWMs. See Appendix 2 for more details.

\subsection{Techno-economic analysis}

Two solutions were examined: the installation of a vertical axis wheel with improved efficiency (Figure 1b) and the installation of an impulse Turgo turbine (Figure 1c). For each VAWM site, achievable power and costs were estimated for both solutions. Finally, the installation of a traditional water wheel was also discussed (Figure 1a). In Appendix 3, the sketch of a VAWM is shown.

2.2.1 Turbine choice. In the context of this study, an impulse turbine was chosen for the following motivations: (1) the authority in charge of the preservation of the cultural heritage (e.g. the Soprintendenza dei Beni Culturali for the Italian context) often imposes to maintain the esthetic and the cultural aspects of VAWMs; (2) a reaction turbine would be too much expensive in these remote contexts (a Francis turbine requires a draft tube and a spiral case), and it is geometrically/aesthetically different from a water wheel; (3) when the mill is repowered to provide mechanical energy for local purposes (e.g. for grinding grain), the dimensions and the rotational speed of an impulse turbine are more suitable than those of a reaction turbine to be effectively coupled with the milling machines. Therefore, the choice of the turbine type had to be done between a Turgo (Figure 1c) and a Pelton turbine (Figure 1d).

In general terms, the use of a Turgo or a Pelton turbine would not significantly change the perspective, since aesthetics and efficiencies are similar, and manufacturing (e.g. casting and machining) processes are comparable (Cobb and Sharp, 2013). Nevertheless, the aesthetics and geometry of a Turgo turbine is more similar to that of a water wheel (Figure 1), and it exhibits a higher flow capacity, i.e. a smaller diameter and a simpler blade shape.

In this study, the global efficiency of the plant equipped with a Turgo turbine was assumed 70\%, due to the micro size of the plant (Cobb and Sharp, 2013; Gaiser et al., 2016). The solution with the Turgo turbine was also equipped with new nozzles and new pressurized penstock (more expensive solution, but more efficient). With regards to VAWWs, Pujol et al. (2015) stated that the efficiency of a traditional water wheel is $29 \%$, while it is $47 \%$ for an optimized one (e.g. curved blades). The optimized efficiency value thus corresponds to a VAWW properly designed and more efficient than older ones (e.g. Figure 1a) leading to a global mechanical efficiency of a VAWW plant of $35 \%$. In this case it was assumed to maintain the old channel, penstock and headrace (very low cost option, but less efficient). The efficiency value in the latter case was due to the absence of a proper nozzle as in the Turgo turbine (which is very close to the wheel and can be regulated as a function of the flow rate with the minimum head loss) and to the lower efficiency of the wheel. 


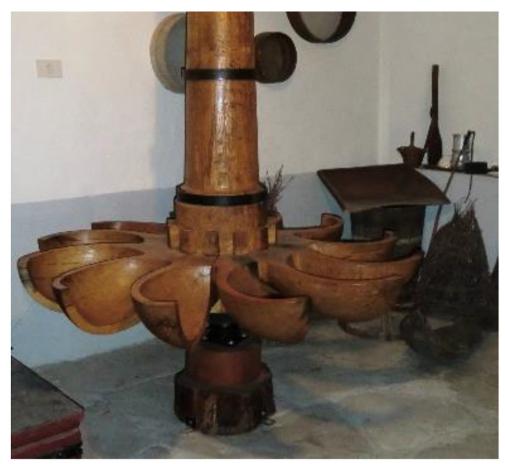

(a)

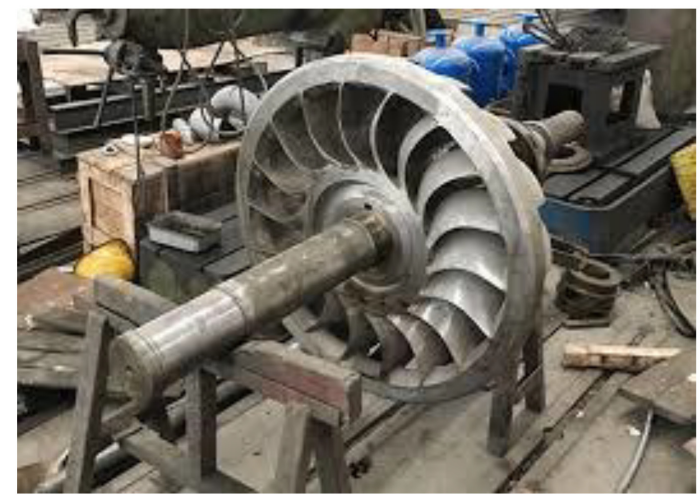

(c)

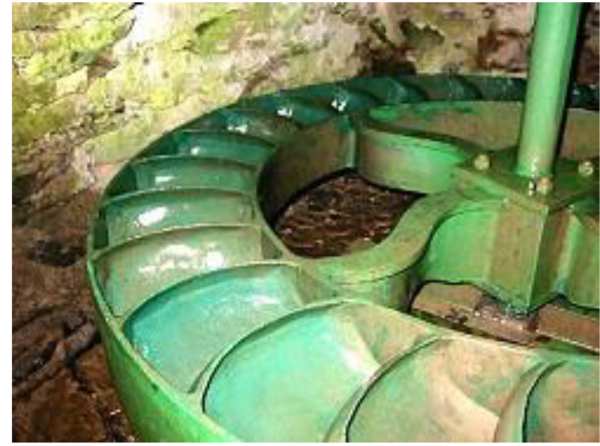

(b)

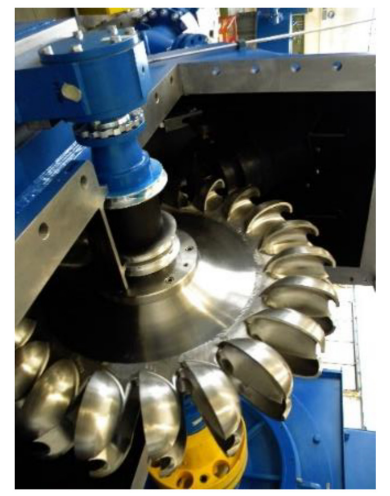

(d)
Figure 1.

(a) Wooden horizontal wheel (Italy, Mulino Chicon, Silvano Bonaiuti) and (b) steel wheel (https:// moulindelamousquere. pagesperso-orange.fr); (c) Turgo turbine and (d) Pelton turbine (Zeco Hydropower)

2.2.2 Turbine and water wheel characteristics. For each mill site of known head and flow, the calculations were performed using the design flow rate $Q_{\text {des }}=0.9 Q_{\max }$, as in the standard design of water wheels and impulse turbines, and because the operating conditions at lower flows can be regulated by nozzles to keep the operation efficient. The following assumptions were made.

(1) For the Turgo turbine, four solutions were investigated, each one with a different number of jets (or nozzles): 1, 2, 3, 4, each jet with an equal amount of flow rate.

(2) A certain number of jets implies a certain jet diameter. The ratio between turbine diameter $D$ and jet diameter $d$ was assumed equal to $D / d=8.5$ (it would have been 12 for a Pelton turbine, Gaiser et al., 2016), so that turbine diameter could be estimated for each number of jets configuration. The maximum wheel diameter must be below $1.5 \mathrm{~m}$ for practical reasons, as reported in Pujol et al. (2010), Pujol and Montoro (2010), Centre for Rural Technology (2014), Rynne (2015) and Çorapçığlu (2016).

(3) The jet velocity $v(\mathrm{~m} / \mathrm{s})$ was calculated as $v=0.9 \sqrt{2 \mathrm{~g} H}$ (Santolin et al., 2011), thus assuming that head losses before the turbine are $19 \%$ of the total head. These losses are already included in the global efficiency value of $70 \%$ for the Turgo turbine. The value $19 \%$ is quite high for a standard impulse plant, but it is herein justified due to the very small size of the plant and the partial reuse of existing structures. In the case 
of the water wheel, friction losses are higher; for example, Pujol et al. (2010) identified a friction coefficient of 0.7 along a headrace of $2 \mathrm{~m}$ with a hydraulic radius of $0.041 \mathrm{~m}$, and also Vashisht (2012) assumed a hydraulic radius of $0.04 \mathrm{~m}$. This would imply a free fall velocity of $0.8 \sqrt{2 \mathrm{gH}}$.

(4) The tangential speed $u$ of the water wheel and the Turgo turbine was set at $40 \%$ of the jet velocity (Gaiser et al., 2016), which was calculated from the above point. Therefore, for each number of jets configuration, a certain rotational speed was calculated.

(5) Rotational speeds $N$ of VAWWs are generally between $N=120$ and $N=160 \mathrm{rpm}$, thus the rotational speed closest to $150 \mathrm{rpm}$ was chosen, with its related diameter, in order to ensure a good grinding working behavior and a cheaper power take-off. When more options for each site were possible, the fastest rotational speed was chosen to reduce turbine dimensions.

In case of electricity generation, a power take-off composed of a gearbox and a generator was used, so that the rotational speed of the turbine was not strictly dependent on the number of poles of the generator. Since $N \sim u D^{-1}$, at a certain tangential blade speed (that was set at $40 \%$ of jet velocity, see above points) the highest rotational speed $N(\mathrm{rpm})$ occurs at the highest number of jets $i$ : at the highest number of jets, the jet diameter $d$, as well as the runner diameter $D$, are the smallest. By using the rotational speed closest to $150 \mathrm{rpm}$, the characteristic speed, as defined in Santolin et al. (2011), ranged from 0.12 to 0.29, in line with the proposed range of 0.04-0.4 for impulse turbines suggested in Santolin et al. (2011).

(6) The width of the turbine and the width of the wheel were assumed 2.5 and 3 times the water jet, respectively, as for standard design of impulse turbines.

2.2.3 Costs. In general, the cost of the electromechanical equipment can be estimated from data of Ogayar et al. (2009) and Santolin et al. (2011). The cost of the mechanical part is generally $33 \%$ of the total electromechanical equipment cost (Van Vuuren et al., 2011). However, considering that the unit cost $(€ / \mathrm{kW})$ decreases as the power of the unit increases, Ogayar equations would not be appropriate in this context, because they were conceived for larger plants than those here investigated (herein typically below $10 \mathrm{~kW}$ ). Therefore, the data coming from Heidra (pers. comm. of Steve Ritchie) were used to compute the costs of the Turgo runner. It was assumed that the cost of the Turgo runner scales fairly linearly with the diameter, and the reference data are $8,100 €$ for $0.4 \mathrm{~m}$ runner. The cost of the spear lets + actuator is $6,700 €$ for $70 \mathrm{~mm}$ jet diameter. New style off assembly (weldless) is generally used in this kind of turbines, as well as the technique to prestress the blade root. In this way, the cost is $\frac{8100}{0.4} D$ for the runner and $\frac{6700}{0.07} d \cdot i$ for the nozzle, where $D=$ runner diameter $(m), d=$ jet diameter $(m)$ and $i=$ number of jets. The number of jets affects the jet diameter, and thus the turbine diameter, so that the cost of the runner decreases with the number of jets, while the cost of nozzles increases with the number of jets. Hence there is a certain number of jets that minimizes the costs. In our study, it was found that the minimum cost was $7 \%$ lower than the maximum cost, and it occurred at 2 or 3 jets. Therefore, since this cost difference is not significant in the context of our study, it was chosen the number of jets that allowed to obtain the rotational speed closest to $150 \mathrm{rpm}$ was chosen (for a better performance of the whole system) rather than the cheaper solution.

The cost of the polyester penstock was estimated applying the equation proposed in Santolin et al. (2011).

The cost of the water wheel was calculated as a function of wheel diameter and width. The cost of a water wheel of $2.5 \mathrm{~m}$ in diameter and $0.5 \mathrm{~m}$ wide (based on personal communication of the Italian company Gatta srl) was taken as reference and normalized by the product of the width $B(\mathrm{~m})$ by the diameter $D(\mathrm{~m})$. In this way, the cost of a water wheel could be estimated as 
$7,680 B D(€)$, which is also in line with UK prices taken from the Waterwheel Factory website. No pressurized penstock was considered, since it was assumed to retrofit the existing penstock.

The costs of the gearbox $C_{g}$ and the electric generator $C_{e g}$ for electricity generation were calculated from Bonfiglioli s.p.a. as $C_{g}=50 P+323$ (€) (gearbox), and $C_{e g}=51 P+52$ (€) (in agreement with prices from BBSERVICESTORE and Idroenergiaitalia available on the web), where $P(\mathrm{~kW})$ is the mechanical power. These costs are valid within the range here investigated. Costs of electromechanical equipment include the $20 \%$ VAT. The electromechanical efficiency was assumed to be $90 \%$.

The techno-economic analysis was applied to the 714 vertical axis mills of known head and flow rate collected in our database. The mechanical power $P(\mathrm{~kW})$ was calculated by Eq. (1), where $Q$ is the flow rate $\left(\mathrm{m}^{3} / \mathrm{s}\right), H$ is the head (m), $\eta$ is the mechanical efficiency $(70 \%$ and $35 \%$, for Turgo turbines and water wheels, respectively). The electric power $P_{e l}$ was calculated by multiplying (Eq. 1) by the efficiency of the power take-off, which was assumed $90 \%$ (Eq. 2).

$$
\begin{gathered}
P=9.81 Q H \eta \\
P_{e l}=0.9 \cdot 9.81 Q H \eta
\end{gathered}
$$

\section{Results}

In this section, results are discussed to compare the Turgo turbine option with the optimized water wheel. In the Discussion section further comments are provided for a traditional water wheel.

From Figure 2 it can be seen the prevalence of heads, average flow rates and average mechanical power (Eq. 1, using the average flow $Q_{a v g}$ ) of the mills. The average head is $H=7.6 \mathrm{~m}$, ranging from $2.8 \mathrm{~m}$ to $15 \mathrm{~m}$, with an average flow of $110 \mathrm{l} / \mathrm{s}$, ranging from $10 \mathrm{l} / \mathrm{s}$ to $400 \mathrm{l} / \mathrm{s}$.

From these data, the value of the maximum flow $Q_{\max }$ that can be generally exploited with a fixed head is $Q_{\max }=0.6-0.033 \mathrm{H}$, with $Q_{\text {max }}$ expressed in $\mathrm{m}^{3} / \mathrm{s}$ (Figure 3 ). This equation can be used to verify the suitability of a certain site for a VAWW. If this equation is for example applied to the 165 mills listed in Morganti and Semprini (1999), where 89 are with known head and flow, 49 mills lie within the range expected for vertical axis mills, with an average head of $5.1 \mathrm{~m}$ and average flow of $160 \mathrm{l} / \mathrm{s}$. An additional Italian example is the Gragnano mill (pers. comm. of Pietro Ingenito), with $H=6.5 \mathrm{~m}$ and $Q_{\max }=100 \mathrm{l} / \mathrm{s}$.

Figure 4 shows the diameter of the runner versus the flow rate, for different numbers of jets. Accordingly, the diameter size reduces with the number of jets because of the smaller
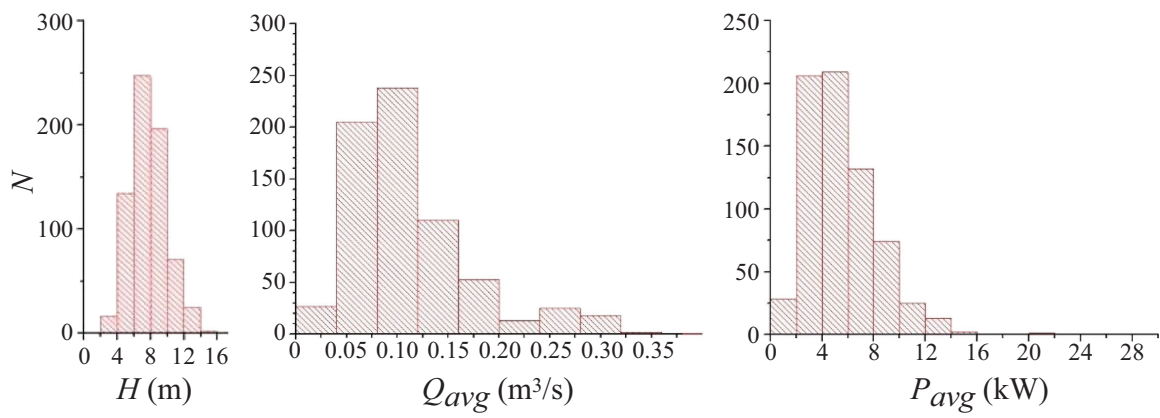

Figure 2. Site characteristics of the collected water mills (number of sites $N$, head $H$ and average flow $Q_{\text {avg }}$ ) and average power at the average flow, for Turgo turbines. When considering the water wheels, the power values halve due to the half efficiency 


\section{JCHMSD}

\section{Figure 3.}

Flow rate versus head for the collected vertical axis mills. The lower the discharge, the higher is the mill tower (head $H$ )
Figure 4.

Diameter of runner (Turgo turbine and water wheel) as a function of the flow rate, for different numbers of jets/ nozzles $i$
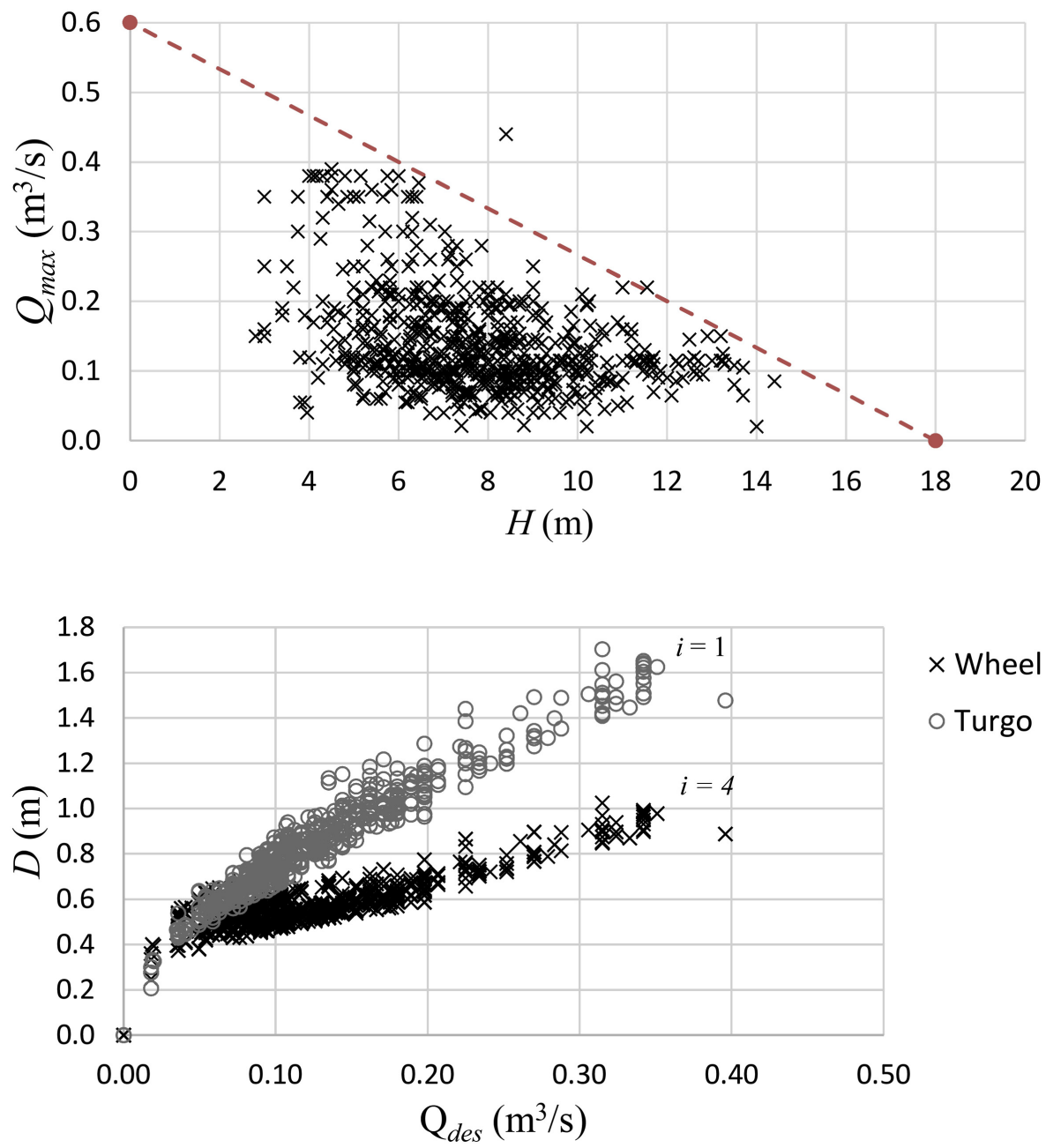

water jet diameter and, therefore, the bucket dimensions. One water jet was chosen for the water wheel (as in real applications), leading to a wider wheel than the Turgo turbine.

The average diameter of the Turgo turbine is $0.58 \mathrm{~m}$ for an average rotational speed of $151 \mathrm{rpm}$, while the average wheel diameter is $0.85 \mathrm{~m}$ for an average rotational speed of $123 \mathrm{rpm}$. When these mills are rehabilitated with Turgo turbines, the average value of the mechanical power (Eq. 1) $P_{\text {avg }}$ is $5.7 \mathrm{~kW}$ (calculated with $Q_{\text {avg }}$ ), and the average value of $P_{\text {max }}$ (calculated with $Q_{\max }$ ) is $7.1 \mathrm{~kW}$, while it is 2.84 and $3.55 \mathrm{~kW}$ for the optimized water wheel. The electric power can be calculated by multiplying the mechanical power by 0.9 (Eq. 2).

The average cost of a Turgo turbine was $39,100 €$ (with gearbox and generator for electricity generation) and $38,000 €$ (without electrical equipment), for an average cost of $7,760 € / \mathrm{kW}$ and $6,796 € / \mathrm{kW}$, respectively. The electric power (Eq. 2) and the mechanical power (Eq. 1), respectively, were used to calculate the above mentioned unit cost per $\mathrm{kW}$, considering the design flow $Q_{d e s}$. Costs are comparable with pico PAT (pump as turbine), 
where an initial cost of 25,000 € was estimated in Motwani et al. (2013) for a $3 \mathrm{~kW}$ application, and around 5,000 €/kW in Garcia et al. (2019), when installed at existing nodes in pressurized networks. Considering the water wheel, the average price is 3,014 $€$ (with gearbox and electric generator) and 2,107 $€$ (without gearbox and generator), or $1,112 € / \mathrm{kW}$ and 687 $€ / \mathrm{kW}$, respectively, calculated as mentioned above. Results are in line with Agarwal (2006), where 810 \$USD $(675 €$ ) were spent to repower a mill for grinding $25-30 \mathrm{~kg} / \mathrm{h}$ of grain, thus with an estimated power of $0.58 \mathrm{~kW}$ (estimated from the first line of Table A1): with these data, the cost can be quantified in $1,155 € / \mathrm{kW}$. When considering the electricity generation, the electric power was used to compute the cost per $\mathrm{kW}$ (Eq. 2). The results are in line with two case studies described in Appendix 3, where the cost of a VAWM repowering (with a modern water wheel) was found to be between $1,980 € / \mathrm{kW}$ and $3,000 € / \mathrm{kW}$.

Figure 5 depicts the costs of the electromechanical equipment for electricity generation. The equation of Ogayar et al. (2009) (conceived for Pelton turbines), would underestimate by $15 \%$ (on average) the cost of a Turgo turbine. Therefore, by adapting Ogayar equation to our study, Eq. (3) and Eq. (4) were obtained to estimate the cost of Turgo turbines and VAWWs, respectively, for electricity generation. These equations are valid within the range here investigated.

$$
\begin{aligned}
& C_{\text {turgo }}=49,252 P_{e l}^{0.50} H^{-0.56} \\
& C_{\text {wheel }}=8,628 P_{e l}^{0.86} H^{-1.04}
\end{aligned}
$$

where, $P_{e l}$ is the electric power $(\mathrm{kW})$ calculated with $Q_{\text {des }}, H$ is the head $(\mathrm{m})$ and $C_{\text {turgo/wheel }}$ the cost in $€$. The average discrepancy from the full estimate is 1.6 and $2.0 \%$, respectively.

The power developed by a Turgo turbine is twice that of a VAWW, but the cost is more than 10 times higher, depending on the number of jets, so that the cost per $\mathrm{kW}$ is, on average, 7 times higher. Due to the low electric power (generally below $10 \mathrm{~kW}$ ) the cost of the power takeoff is negligible with respect to the cost of the runner.

The minimum power requirement for some mill activities is reported in Table A1 (Appendix 1). The number of cases where the average power (Eq. 1 with $Q_{a v g}$ ) is higher than the minimum required one is 689 with the Turgo turbine and 679 with the water wheel. Globally, the power in excess (calculated as $P_{\text {avg }} P_{\text {required }}$ ) is $1,433 \mathrm{~kW}$ for water wheels and $3,400 \mathrm{~kW}$ for Turgo turbines, that is, on average, $2.0 \mathrm{~kW}$ per plant and $4.8 \mathrm{~kW}$ per plant, respectively, considering the 714 mills here investigated. Therefore, with a Turgo turbine, in addition to the mill activities, enough electricity can be generated to be delivered to the grid, or used for other purposes, but the installation costs would be higher, as previously discussed.

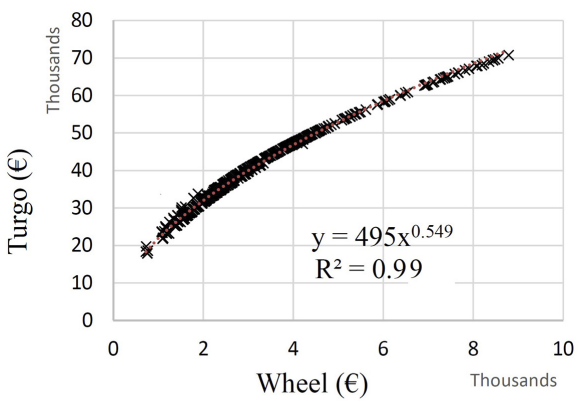

(a)

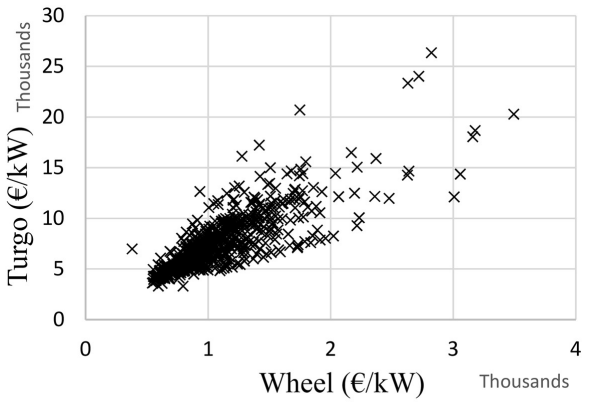

(b)
Figure 5.

Cost of Turgo turbines versus cost of the water wheel for electricity generation. Total cost

(a) and $\operatorname{cost} / \mathrm{kW}$ (b) mechanical equipment of water mills 


\section{Discussion}

In the Results section, the achievable power and related electromechanical equipment costs were estimated, both for the Turgo turbine and for the optimized water wheel, showing that the Turgo turbine is more expensive, but more powerful. In this section, the obtained results are discussed with the aim of providing useful considerations to support techno-economic choices in this context.

The retrofitting and repowering of an old VAWM require different works, listed as follows:

(1) Electromechanical equipment (addressed in this work).

(2) Transport, installation, maintenance costs.

(3) Electrical connections and bureaucratic issues.

(4) Civil and architectural works.

On the other side, economic incomes are the following ones:

(1) Electricity sale within the electricity market, or for self-sustainment.

(2) Local productions (e.g. oil, floor, see Table A1).

(3) Entrance tickets in case of conversion into a museum.

(4) Social benefits not directly quantifiable: tourisms and related activities in rural areas, events, etc.

(5) Maintenance of the surrounding rural and natural landscape.

For example, the Authors are aware of the case of Gragnano mill (Italy), where the material costs related to 2 VAWWs, 2 millstones, 1 hopper and civil works were quantified in 40,000€ (pers. comm. of Pietro Ingenito). The costs incurred in 2001 by Mulino di Bobbio Pellice (pers. comm. of Emanuela Genre) were 16,000,000 lire, including the restoration of the mechanical equipment (excluding the overshot water wheel) and the instrumentations (millstone, transmission equipment, drive belt, sifter and elevator). The retrofitting of the overshot wheel costed $12,000 €(D=2.6 \mathrm{~m}, B=0.9 \mathrm{~m})$ in 2003. The costs incurred in 2004 by Mulino Cornaleto (pers. comm. of the owner Michele Nardi) related to 2 VAWWs, 2 hoppers and restoration works (made in order to preserve the original stone structure) were quantified in $200,000 €$ (with a contribution from the Italian Soprintendenza equal to $1 / 3$ of the total). The cost to rebuild the $2.1 \mathrm{~m}$ long shaft of the VAWW of Mulino Parrini (Italy), with a VAWW $1.4 \mathrm{~m}$ diameter, was $800 €$ (pers. comm. Giovanna Recati).

With regards to the economic incomes, in addition to electricity generation and sale of local products, it has to be considered the entrance tickets and the promotion of tourism in the surroundings. For example, the entrance ticket at the Conqueta mill (Appendix 3) is $7 €$ for people older than 7 years old; the number of people visiting it can be estimated at 100 per week that in summer months may be higher. Instead, in Italy it is not very common to pay for a visit in a mill, even if during the 2019 "Heritage Days" more than 200 hundreds visitors visited the Cornaleto mill, in Potenza (Basilicata) and they gave a free contribution from $3 €$ to $10 €$.

However, within the scope of this study it is not possible to carry out a complete costbenefit analysis, since the above listed costs and benefits are site specific. Nevertheless, a discussion based on the obtained results of the electromechanical equipment can be carried out, for example, estimating its payback time in case of electricity sale. To calculate the payback time, the Italian tariff of $0.155 € / \mathrm{kWh}$ can be assumed. The annual economic income from the electricity sale also depends on the annual operating hours. The annual operating hours highly depend on the water level and flow variation: flow variations would greatly 
affect the water wheel performance, while for Turgo turbines, that have a proper regulation system, the functioning is much more homogeneous. Furthermore, in certain cases, due to the low power output of water wheels, water wheels may not be suitable for electricity generation. However, 4,000 $\mathrm{h}$ per year for Turgo turbines (at the average flow) and 2,000 $\mathrm{h}$ per year for the water wheel can be assumed. With these assumptions, the payback time of the electromechanical equipment would be 13.6 years and 3.9 years for Turgo turbines and optimized water wheels, respectively (calculated assuming only the costs estimated in this work, thus excluding maintenance, installation and transport costs, that are site specific). Therefore, although it is not possible to know exactly the operating hours, since they are site specific, the order of magnitude of the calculated values can be considered reasonable to provide realistic discussions. In this assessment we did not consider the other costs and additional economic incomes, thus the estimated payback time has to be strictly interpreted as the time required to pay the electromechanical equipment by the sale of electricity. The cost of Turgo turbines may reduce in the near future due to the development of novel manufacturing processes and innovative and lighter materials, e.g. composite (Quaranta and Davies, 2021).

Finally, Table 1 presents a general overview of average results for the Turgo option, the optimized water wheel and, furthermore, for a traditional (not optimized) water wheel, assuming a traditional water wheel efficiency of $29 \%$ with straight blades (Pujol et al., 2015) and a global plant efficiency of $20 \%$. The same cost of the optimized water wheel was assumed, although it may be slightly lower due to the straighter blades. The Turgo turbine is the option to maximize the long-term profit, despite the higher installation cost, while the optimized water wheel is the optimal solution when the scope is to reduce installation costs and payback time of the equipment.

The results discussed in this work refer to water mills equipped with optimized water wheels, e.g. following the guidelines described in recent papers (e.g. Pujol et al., 2015). With an optimized water wheel, the production of grinding grain per unit time can increase on the order of, at least, $60 \%$ (from 10 to $13 \mathrm{~kg}$ grains per hour to $16-20 \mathrm{~kg}$ grains per hour), with respect to an original water wheel. Although it is lower than that obtained with modern turbines (25-30 kg grains per hour), it seems very promising in terms of the high adoptability rate of the proposed upgrading (Pujol et al., 2015).

\section{Conclusions}

The research carried out to collect the database of VAWMs in Basilicata has highlighted the importance of archival cartographic sources for the census of historical mills, as the only source that can provide precise information of the mills location at a large scale. However, the difficulty of this process highlighted the need of digitalizing the historic databases and maps,

\begin{tabular}{|c|c|c|c|c|}
\hline Average results & $\begin{array}{c}\text { Traditional water } \\
\text { wheel }\end{array}$ & $\begin{array}{c}\text { Optimized water } \\
\text { wheel }\end{array}$ & $\begin{array}{l}\text { Turgo } \\
\text { turbine }\end{array}$ & \\
\hline Global mechanical efficiency (\%) & 20 & 35 & 70 & \\
\hline Average diameter $(\mathrm{m})$ & 0.85 & 0.85 & 0.58 & \\
\hline Average power (and with average flow) (kW) & 1.6 & 2.8 & 5.7 & \\
\hline Average electromechanical cost $(€)$ & $\sim 3,330$ & $\sim 3,000$ & $\sim 39,000$ & Table 1 . \\
\hline Average unit cost $(€ / \mathrm{kW})$ & $\sim 1,900$ & $\sim 1,100$ & $\sim 7,800$ & Summary of average \\
\hline $\begin{array}{l}\text { Payback time of the electromechanical } \\
\text { equipment (years) }\end{array}$ & 6.8 & 3.9 & 13.6 & $\begin{array}{r}\text { results (obtained } \\
\text { averaging the results of }\end{array}$ \\
\hline Income in 20 years (assuming $0.155 € / \mathrm{kWh}$ ) & 9,920 & 17,360 & 70,680 & all the database entries) \\
\hline
\end{tabular}

Electromechanical equipment of water mills 
in order to facilitate researchers and operators in this sector. The collected database was analyzed performing a techno-economic analysis to support the repowering of these mills. The produced power can be exploited to generate mechanical energy for the mill activities, or for electricity generation, that can be locally consumed or delivered to the grid.

Guidelines to calculate the suitable diameter and equations to estimate the maximum flow rate suitable for a VAWW and the electromechanical equipment costs were presented. Results show that the Turgo turbines generate twice the power of a vertical water wheel, but at a higher investment cost. The payback time of the electromechanical equipment is, on average, 15 years for Turgo turbines and 4.3 years for water wheels, but in 20 years the economic income from the electricity sale achieved from a Turgo turbine would be four times that of a water wheel. Therefore, the Turgo turbine should be used when the aim is to achieve a higher power, or when the electricity has to be delivered to the grid, maximizing the longterm profit. The water wheel, despite the lower efficiency, is cheaper and should be preferred for low power requirements or for retrofitting works aimed at preserving the cultural heritage and stimulates cultural tourism. In our analysis, we did not consider costs related to transport, installation and those related to civil works, as well as economic incomes related to touristic and local activities, because they are site specific and are expected to be similar for Turgo turbines and water wheels.

Considering the wide range of hydraulic conditions investigated in this work, results can be considered of general validity to support the retrofitting and repowering of VAWMs. It is worth noting that costs are mainly private, while some benefits are also public, e.g. the preservation of the cultural heritage, social attraction and tourism promotion.

\section{References}

Agarwal, S.K. (2006), "Re-energizing watermills for multipurpose use and improved rural livelihoods", Mountain Research and Development, Vol. 26 No. 2, pp. 104-108.

Avitsur, S. (1969), "Watermills in Eretz Israel, and their contribution to waterpower technology", Transactions of the Second International Symposium on Molinology, Brede, pp. 393-397.

Barceló, M. (2004), "The missing water mill: a question of technological diffusion in the high middle ages. The making of feudal agricultures?", in Sigaut, F. and Barceló, M. (Eds), The Transformation of the Roman World, E.J. Brill, Leiden-Boston, MA, Vol. 14, pp. 255-314.

Behari, P.C. and Bhardwaj, A.K. (2014), "A case study of improved watermill using power electronics devices for Offgrid power generation", Research Journal of Applied Sciences, Engineering and Technology, Vol. 7 No. 2, pp. 417-423.

Bennett, R. and Elton, J. (1898-1904), History of Corn Milling, Vol. 4, Burt Franklin, New York.

Bozhinova, S., Hecht, V., Kisliakov, D., Müller, G. and Schneider, S. (2013), "Hydropower converters with head differences below 2.5 m", Proceedings of the Institution of Civil Engineers-Energy, Vol. 166 No. 3, pp. 107-119.

Brykała, D. and Podgórski, Z. (2020), "Evolution of landscapes influenced by watermills, based on examples from Northern Poland", Landscape and Urban Planning, Vol. 198, 103798.

Buonora, P. (2010), "La presenza e la diffusione delle ruote idrauliche nell'Appennino e nella storia della tecnologia", in Energia e macchine. L'uso delle acque nell'Appennino centrale in età moderna e contemporanea, CRACE, Narni.

Centofanti, M., Brusaporci, S., Di Donato, A. and Lucchese, V. (2013), "Water mills for cereal grinding and copper processing", in IFToMM Workshop on History of MMS - Palermo, pp. 10-18.

Centre for Rural Technology, Nepal (2014), Improved Water Mill Development in Nepal: A Status Review, Published with support from, SNV Netherlands Development Organisation, Bhanimandal, Lalitpur, ISBN: 978-9937-2-7575-0. 
Cobb, B.R. and Sharp, K.V. (2013), "Impulse (Turgo and Pelton) turbine performance characteristics and their impact on pico-hydro installations", Renewable Energy, Vol. 50, pp. 959-964.

Conqueta water mill (2021), available at: http://www.santfeliudepallerols.cat/coneix/llocs-dinteres/elsmolins-moli-de-la-conqueta/.

Çorapçıŏlu, G. (2016), "Conservation of the traditional water mills in the Mediterranean Region of Turkey”, Cultural Heritage Management and Sustainable Development.

Curwen, E.C. (1944), “The problem of early water-mills”, Antiquity, Vol. 18 No. 71, pp. 130-146.

Dupin, C. (1828), Forces productives et commerciales de la France, Jobard Freres, Brussels.

Durand, R. (2003), "Les moulins hidrauliques dans le Portugal médiéval”, in I Mulini nell'Europa Medievale, Bologna, pp. 87-99.

Fajer, M. (2018), "Changes in river channel pattern as a result of the construction, operation and decommissioning of watermills-the case of the middle reach of the River Liswarta near Krzepice, Poland”, Environmental and Socio-Economic Studies, Vol. 6 No. 1, pp. 25-37.

Gaiser, K., Erickson, P., Stroeve, P. and Delplanque, J.P. (2016), "An experimental investigation of design parameters for pico-hydro Turgo turbines using a response surface methodology", Renewable Energy, Vol. 85, pp. 406-418.

García, I.F., Novara, D. and Mc Nabola, A. (2019), "A model for selecting the most cost-effective pressure control device for more sustainable water supply networks", Water, Vol. 11 No. 6, p. 1297.

Genise, G. (2011), La via dei mulini ad acqua nell'alto Jonio, Nostra Italia onlus, Lucca.

Grano, M.C. (2017), "Horizontal drop tower watermill location and fluvial dynamics in Basilicata (Southern Italy). Hydrographic maps, archive sources, AIR photographs and GIS analysis for the study of water power systems from late 1700 to 1900”, PhD Thesis at, Università Sapienza di, Roma.

Grano, M.C. (2020), "Gualchiere, mulini idraulici e cisterne. L'uso dell'acqua e le trasformazioni del paesaggio in Basilicata/Hydraulic fullers, cereal mills and tanks. Use of water and landscape transformation in Southern Italy", Agri Centuriati, Vol. 17, pp. 47-57, doi: 10.19272/ 202009101004.

Grano, M.C. and Lazzari, M. (2017), "Mulini idraulici a ruota orizzontale. Costruzione, principali danni e manutenzione nella Basilicata del XIX secolo, in Tecnica di idraulica antica", Supplemento a Geologia dell'Ambiente, Vol. 3 No. 201, pp. 208-215, ISBN: 1591-5352.

Grano, M.C., Del Monte, M., Bishop, P. and Lazzari, M. (2016), "Fluvial dynamics and water mills location in Basilicata (Southern Italy)", Geografia Fisica e Dinamica Quaternaria, Vol. 39 No. 2, pp. 149-160.

Hunter, L.C. (1979), “A history of industrial power in the United States, 1780-1930”, in Waterpower in the Century of the Steam Engine, University Press of Virginia, Charlottesville, Vol. 1.

Kur, F. and Wolf, H.G. (1985), Wassermühlen, Eichborn, Frankfurt.

Lucas, A. (2011), Wind, Water, Work: Ancient and Medieval Milling Technology, Brill, Leiden.

McGuigan, D. (1978), Small Scale Water Power, Wheaton \& Co, Exeter.

Minami, R. (1982), "Water wheels in the preindustrial economy of Japan”, Hitotsubashi Journal of Economics, pp. 1-15.

Morganti, L. and Semprini, M. (1999), I Mulini Della Valmarecchia La Mandragora, Santarcangelo di Romagna.

Motwani, K.H., Jain, S.V. and Patel, R.N. (2013), “Cost analysis of pump as turbine for pico hydropower plants-a case study", Procedia Engineering, Vol. 51, pp. 721-726.

Müller, W. (1899), Die Eisernen Wasserräder. Erster Teil. Die Zellenräder, Verlag von Veit \& Comp., Leipzig. mechanical

equipment of

water mills 
Ogayar, B., Vidal, P.G. and Hernandez, J.C. (2009), "Analysis of the cost for the refurbishment of small hydropower plants”, Renewable Energy, Vol. 34 No. 11, pp. 2501-2509.

Pujol, T. and Montoro, L. (2010), "High hydraulic performance in horizontal waterwheels", Renewable Energy, Vol. 35 No. 11, pp. 2543-2551.

Pujol, T., Solà, J., Montoro, L. and Pelegrí, M. (2010), "Hydraulic performance of an ancient Spanish watermill”, Renewable Energy, Vol. 35 No. 2, pp. 387-396.

Pujol, T., Vashisht, A.K., Ricart, J., Culubret, D. and Velayos, J. (2015), "Hydraulic efficiency of horizontal waterwheels: laboratory data and CFD study for upgrading a western Himalayan watermill”, Renewable Energy, Vol. 83, pp. 576-586.

Punys, P., Kvaraciejus, A., Dumbrauskas, A., Šilinis, L. and Popa, B. (2019), "An assessment of microhydropower potential at historic watermill, weir, and non-powered dam sites in selected EU countries", Renewable Energy, Vol. 133, pp. 1108-1123.

Quaranta, E. (2018), "Stream water wheels as renewable energy supply in flowing water: theoretical considerations, performance assessment and design recommendations", Energy for Sustainable Development, Vol. 45, pp. 96-109.

Quaranta, E. and Davies, P. (2021), "Emerging and innovative materials for hydropower engineering applications: turbines, bearings, seals, dams and waterways", Engineering, in press.

Quaranta, E. and Müller, G. (2018), "Sagebien and Zuppinger water wheels for very low head hydropower applications", Journal of Hydraulic Research, Vol. 56 No. 4, pp. 526-536.

Quaranta, E. and Revelli, R. (2016), "Optimization of breastshot water wheels performance using different inflow configurations", Renewable Energy, Vol. 97, pp. 243-251.

Quaranta, E. and Revelli, R. (2018), "Gravity water wheels as a micro hydropower energy source: a review based on historic data, design methods, efficiencies and modern optimizations", Renewable and Sustainable Energy Reviews, Vol. 97, pp. 414-427.

Quaranta, E. and Revelli, R. (2020), "Performance optimization of overshot water wheels at high rotational speeds for hydropower applications", Journal of Hydraulic Engineering, Vol. 146 No. 9, 06020011.

Quaranta, E. and Wolter, C. (2021), "Sustainability assessment of hydropower water wheels with downstream migrating fish and blade strike modelling", Sustainable Energy Technologies and Assessments, Vol. 43, 100943.

Rojas-Sola, J.I. and Lopez-Garcia, R. (2007), "Engineering graphics and watermills: ancient technology in Spain”, Renew Energy, Vol. 32, pp. 2019-2033.

Rynne, C. (2000), Working with Water in Medieval Europe: Technology and Resource Use, in Squatriti, P. (Ed.), E. M. Brill, Leiden, pp. 1-50.

Rynne, C. (2015), "The technical development of the horizontal water wheel in the first millennium AD: some recent archaeological insights from Ireland", The International Journal for the History of Engineering and Technology, Vol. 85 No. 1, pp. 70-93.

Santolin, A., Cavazzini, G., Pavesi, G., Ardizzon, G. and Rossetti, A. (2011), "Techno-economical method for the capacity sizing of a small hydropower plant", Energy Conversion and Management, Vol. 52 No. 7, pp. 2533-2541.

Szabó, Z. and Sallay, Á. (2019), "Assets of water mills in Hungary", Proceedings of the Fábos Conference on Landscape and Greenway Planning, Vol. 6 No. 1, p. 18.

Van Vuuren, S.J., Blersch, C.L. and Van Dijk, M. (2011), "Modelling the feasibility of retrofitting hydropower to existing South African dams", Water SA, Vol. 37 No. 5, pp. 679-692.

Vashisht, A.K. (2012), "Current status of the traditional watermills of the Himalayan region and the need of technical improvements for increasing their energy efficiency", Applied Energy, Vol. 98, pp. 307-315.

Wikander, O. (1985), "Archaeological evidence for early water mills - an interim report", History of Technology, Vol. 10, pp. 151-179. 
Wikander, O. (2000), Handbook of Ancient Water Technology, Brill, Leiden.

Wilson, A. (2002), "Machines, power and the ancient economy", The Journal of Roman Studies, Vol. 92, pp. 1-32.

\section{Further reading}

Grano, M.C. (2018), "Archive sources and field surveys used to analyse horizontal-wheeled watermills, their position and technology, in the Basilicata Region of Southern Italy", International Molinology, Vol. 97, pp. 13-19.

Grano, M.C. and Bishop, P. (2017), "Barcelò's missing water mills' and Scottish and Southern Italian horizontal mills", Vernacular Buildings, Vol. 40, pp. 109-122.

Grano, M.C. and Lazzari, M. (2016), "Fonti cartografiche per l'analisi del paesaggio fluviale e dei mulini ad acqua in Basilicata: criticità e vantaggi della Carta Idrografica del Regno d'Italia”, Bollettino Associazione Italiana di Cartografia, Vol. 157, pp. 4-18.

Nomikos, S. (1999), "Identifying, recording and evaluating water powered installations in the

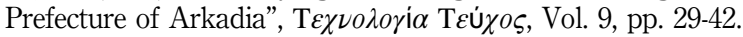




\section{Appendix 1 \\ Historic research on vertical axis water mill}

It is difficult to ascertain the exact date of the water mill "invention" because of the fragmentary nature of the literary and archaeological evidence (Lucas, 2011, p. 9). Classical Greek and Latin sources did not semantically differentiate between different types of mills, and the diffusion of the VAWM in late Roman and medieval times has been underestimated, despite the existence of much evidence for such diffusion (Bennet and Elton, 1898-1904; pp. 6, 12; Curwen, 1944; Grano, 2017). Throughout most of the 20th century, the VAWM was usually thought to be the earliest (oldest) stage of hydraulic grinders when compared to the more efficient and powerful horizontal axis mill (Curwen, 1944, p. 134), but archaeological findings contradict this hypothesis and show that the VAWM is three centuries younger than the horizontal one (Grano, 2020). Furthermore, archaeological findings highlight at least three different types of VAWM.

(1) The first archaeological evidences for VAWMs date to the late 3rd or early 4th century and are related to the more efficient and sophisticated type, which are the triple-helix turbines of Chemtou and Testour in Tunisia (Wikander, 1985, p. 152; Wikandler, 2000, p. 377; Grano, 2017).

(2) A vertical drop tower penstock horizontal-wheeled water mill (Wikander, 1985, p. 152; Wikandler, 2000, p. 377; Lucas, 2011, pp. 70-71) found at the Crocodilion River in Palestine and dated by radiocarbon to 345-380 AD (Wikander, 2000, p. 377; Grano, 2017).

(3) A chute horizontal-wheeled water mill; the first one dates back to the 7th century and is from Ireland (Rynne, 2000, 2015; Grano, 2017).

Depending on the work to be performed, the required power is presented in Table A1.

Differently from the vertical axis wheels, horizontal axis wheels do not use water jets and can be classified into gravity type and stream type. Gravity wheels mainly use the potential energy of water, i.e. the water weight (Quaranta and Revelli, 2018) and can be classified into overshot (Quaranta and Revelli, 2020), breastshot (Quaranta and Revelli, 2016) and undershot wheels (Quaranta and Muller, 2018), depending on head and flow rate, while stream water wheels use the kinetic energy of a water stream (Quaranta, 2018). In the last decade, the horizontal axis water wheel was again reintroduced in the market for electricity generation. Their hydraulic efficiencies of more than $70 \%$, coupled with their low costs compared to other low head turbines (Bozhinova et al., 2013) and high ecological behavior in relation to downstream migrating fish (Quaranta and Wolter, 2021), have made them cost effective low head hydropower converters. Instead, the application of VAWWs almost disappeared.

Mill activity

Required power $(\mathrm{kW})$

Grinder (maximum 40 kg/hour)

Grinder (maximum 80 kg/hour)

$0.7-1$

Rice huller no 4 (175 kg/hour)

Rice huller no 5 (80 kg/hour)

3.7

Rice huller no 6 (350 kg/hour)

2.2

Allo processing

5.1

Bitten rice mill

0.3

Tea squeezer

4.1

Coffee pulper (roller)

1.5

Coffee pulper (drum) $\quad 0.76$

Oil expeller 4 bolt $\quad 3.7$

Oil expeller 6 bolt $\quad$ 3.7-5.1

Wheat thresher $\quad 0.74$

$\begin{array}{ll}\text { Lokta beater } & 2.2-3.7\end{array}$

Saw mill 1.5

Sugarcane crusher

1-1.5

Water pump

$1-1.5$
1.5

Electricity generation $(3 \mathrm{~kW})$

$3-5$

Source(s): Centre for Rural Technology (2014) 


\section{Appendix 2}

\section{Drop tower penstock or Arubah vertical axis water mill}

The most of the Basilicata water mills are drop tower penstock or Arubah mill (mulino a torre) with a vertical penstock (torre) that delivered water under pressure to turn the wheel. The penstock is approximately vertical, but penstocks with lower gradients can also be found (Grano and Lazzari, 2017). Water filling to the top of the tower penstock gushed out at the bottom through a narrow wooden nozzle (Italian "cannellone"), the size of which could be varied to permit regulation of the flow, especially in relation to seasonal variations in the water supply (Avitsur, 1969, p. 40; Barcelò, 2004, p. 284). In periods of low flow, the tower penstock filled up less frequently, but the mill was still able to operate when it was full (Wilson, 2002, p. 509; Barcelò, 2004, p. 284). The penstock height and shape could change, as could the shape of the wheel and other components.

The tower penstock could be either a cylindrical wooden pipe, a concrete pipe, or round tower built from masonry stone. Field inspections and archival documents confirm that the internal dimension (the diameter) of the tower narrowed toward the base of the tower, both to make the connection with the jet at the tower base and to increase the velocity of the water issuing from the jet onto the cups or blades (vanes) of the horizontal wheels. The mills powered by low discharge streams have the highest towers (Grano et al., 2016). Most grain grinding mills have a tower of 6-8 meters height, whereas fulling mills have lower towers, because the latter required less power than grinding mills (Grano et al., 2016).

\section{Appendix 3}

\section{Spanish case studies}

In Table A2 data of two VAWMs located in the Iberian Peninsula were collected. Figure A1 shows a sketch of a VAWM (Conqueta mill).

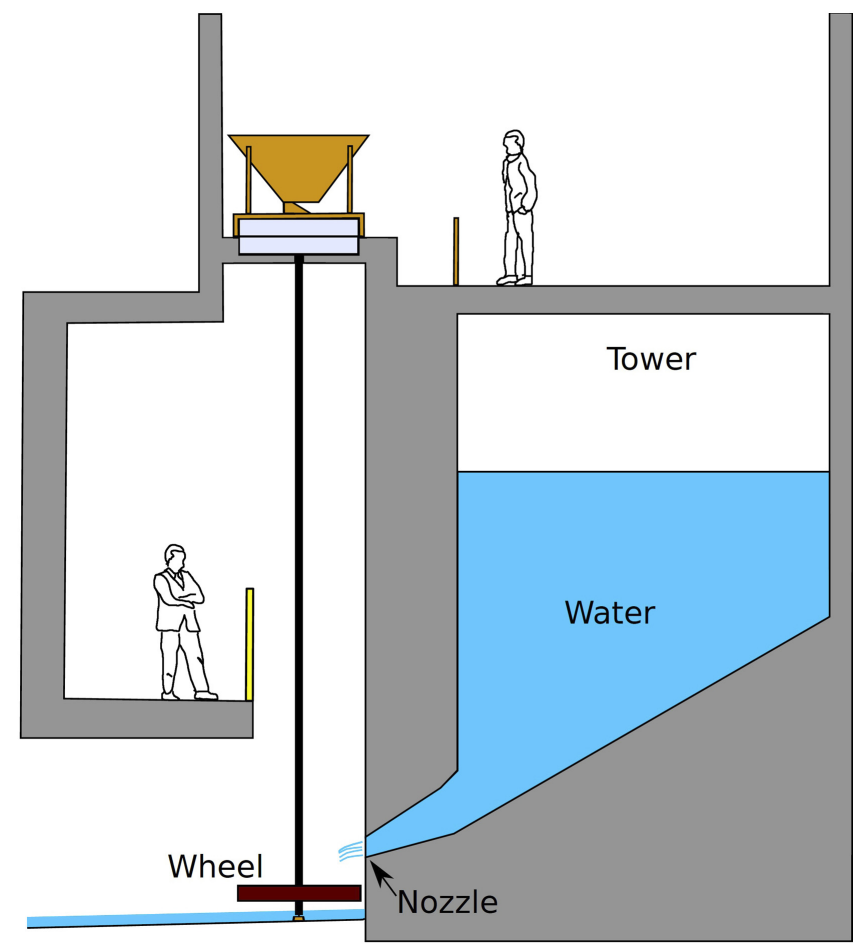

Figure A1. Sketch of a VAWM (Conqueta mill) 


\section{JCHMSD}

Figure A2.

Water mill completely rebuilt in the Colomer farm
The first case study is the Conqueta water mill, located in the town of Sant Feliu de Pallerols (Catalonia region, Spain) that closed in the 1960s and re-opened in 2011 as a touristic attraction (Conqueta water mill, 2021). This water mill has three horizontal wheels, each one of $1.32 \mathrm{~m}$ diameter. Wheels have 24 blades wooden made bolted to a metallic ring that acts as a hub. The unusually large vertical distance from the water wheel center to the static stone $(7 \mathrm{~m})$ requires the use of a metallic axis. The water head is $4.3 \mathrm{~m}$ and the size of the opening gate is $0.16 \times 0.08 \mathrm{~m}^{2}$. The amount of flow rate is approximately $0.10 \mathrm{~m}^{3} / \mathrm{s}$ per wheel. These head and flow rate values lie within the expected ones for the machines studied in the Basilicata region (see Figure 2). The potential energy per unit volume is equal to $\rho g H=4.2 \times 10^{4} \mathrm{~J} / \mathrm{m}^{3}$ so the available power is $\rho g H Q=4.2 \mathrm{~kW}$. By assuming an overall efficiency of $35 \%$, the installed peak power for this site is $\eta \rho g H Q=1.5 \mathrm{~kW}$ per wheel. Note that the free fall water velocity at the opening gate is equal to $0.8 \sqrt{2 \mathrm{gH}}=7.3 \mathrm{~m} / \mathrm{s}$, so the kinetic energy of the water jet per unit volume is $1 / 2 \rho v^{2}=2.7 \times 10^{4} \mathrm{~J} / \mathrm{m}^{3}$. This velocity value multiplied by the opening gate area $\left(0.16 \times 0.08=0.0128 \mathrm{~m}^{2}\right)$ agrees with the approximate flow rate of $0.10 \mathrm{~m}^{3} / \mathrm{s}$. Related with the technoeconomic analysis of Section 2.2, the diameter of this water wheel is found slightly above the expected average value in Figure 4. In terms of cost, the price of rebuilding the whole system (structural + hydraulics) was $4,500 €$ (including VAT), corresponding to a ratio of $3,000 € / \mathrm{kWp}$. This figure is situated in the upper range of Figure 5, most likely due to the long axis needed and the fabrication cost of wooden blades $(929 €)$.

This cost almost coincides with that needed to rebuild a nearby water mill (that of the Colomer farm in the town of la Vall de Bianya) (see Figure A2). In comparison with the previous water wheel, this has the same diameter $(1.32 \mathrm{~m})$ and opening gate area $\left(0.16 \times 0.08 \mathrm{~m}^{2}\right)$. It has 32 blades metallic made and a wooden axis. An outer ring is employed to reinforce the wheel. The water head is $6 \mathrm{~m}$ with a flow rate about $0.11 \mathrm{~m}^{3} / \mathrm{s}$. The free fall water velocity at the opening gate reaches $8.7 \mathrm{~m} / \mathrm{s}$. The peak power installed in this case is $\eta \rho g H Q=2.3 \mathrm{~kW}$ assuming $35 \%$ overall efficiency. Thus, the cost to power ratio is 1,989 $€ / \mathrm{kWp}$, substantially lower than the previous one and in agreement with the values suggested in Figure 5. In this case, the reconstruction of the mill was done to recognize the family heritage. Nevertheless, it admits visits in a county festival week devoted to corn flour in which it grinds this cereal grain. It clearly acts as a tourist appeal to attract visitors to the zone, being announced in several media.
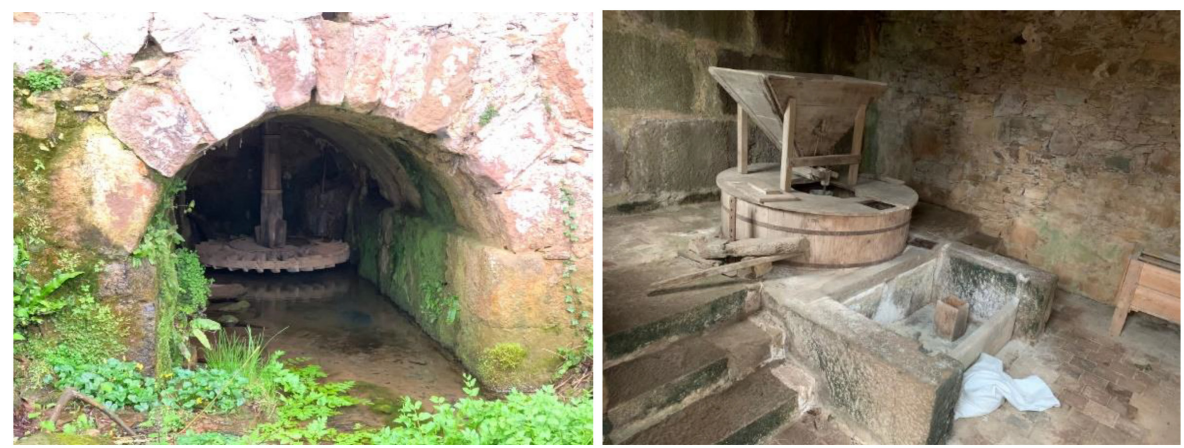


\begin{tabular}{|c|c|c|c|}
\hline & Colomer mill & Conqueta mill & 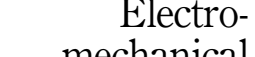 \\
\hline Location & $\begin{array}{l}\text { Town: Vall de Bianya } \\
\text { Lat/Long: } 42.20816,2.45350\end{array}$ & \multirow{2}{*}{$\begin{array}{l}\text { Town: Sant Feliu de Pallerols } \\
\text { Lat/Long: 42.07643, } 2.50769 \\
\text { All }\end{array}$} & equipment of \\
\hline Rebuilding & $\begin{array}{l}\text { Hydraulics of the mill (waterwheel }+ \text { axis) }+ \text { mill } \\
\text { cave + grinding stones }+ \text { water reservoir (only the } \\
\text { crane to lift the upper grinder stone was ok) }\end{array}$ & & water mills \\
\hline \multirow{3}{*}{$\begin{array}{l}\text { Water wheel } \\
\text { dimensions }\end{array}$} & Diameter: $1.32 \mathrm{~m}$ & \multirow{3}{*}{$\begin{array}{l}\text { Diameter: } 1.32 \mathrm{~m} \\
\text { Blade height: } 0.11 \mathrm{~m} \\
\text { Blade number: } 24 \\
\text { Material: wooden blades, metallic } \\
\text { vertical axis }\end{array}$} & \\
\hline & $\begin{array}{l}\text { Blade height: } 0.12 \mathrm{~m} \\
\text { Blade number: } 32\end{array}$ & & \\
\hline & Material: metallic blades, wooden vertical axis & & \\
\hline \multirow[t]{4}{*}{ Hydraulics } & Opening: $16 \times 8 \mathrm{~cm}^{2}$ & Opening: $16 \times 8 \mathrm{~cm}^{2}$ & \\
\hline & Head: $6 \mathrm{~m}$ & Head: $4.27 \mathrm{~m}$ & \\
\hline & Flow rate $=300 \mathrm{~m}^{3} / \mathrm{h}=0.083 \mathrm{~m}^{3} / \mathrm{s}$ & Flow rate $=300 \mathrm{~m}^{3} / \mathrm{h}=0.083 \mathrm{~m}^{3} / \mathrm{s}$ & \\
\hline & Variable rpm & Variable rpm & \\
\hline \multirow[t]{2}{*}{ Purpose } & Grinder grain & Grinder grain & \\
\hline & Recovery of historical heritage (personal use) & Touristic attraction & Table A2. \\
\hline Cost & $4,500 €$ & $\begin{array}{l}4,500 € \text { per wheel (there are three } \\
\text { water wheels in parallel) }\end{array}$ & $\begin{array}{l}\text { Collected data of two } \\
\text { Spanish VAWMs }\end{array}$ \\
\hline
\end{tabular}

\section{Corresponding author}

Emanuele Quaranta can be contacted at: quarantaemanuele@yahoo.it; emanuele.quaranta@ec. europa.eu

For instructions on how to order reprints of this article, please visit our website: 